\title{
CHEIRO DAS TERRAS DE MEU PAI
}

\section{Francisco Renato Lima}

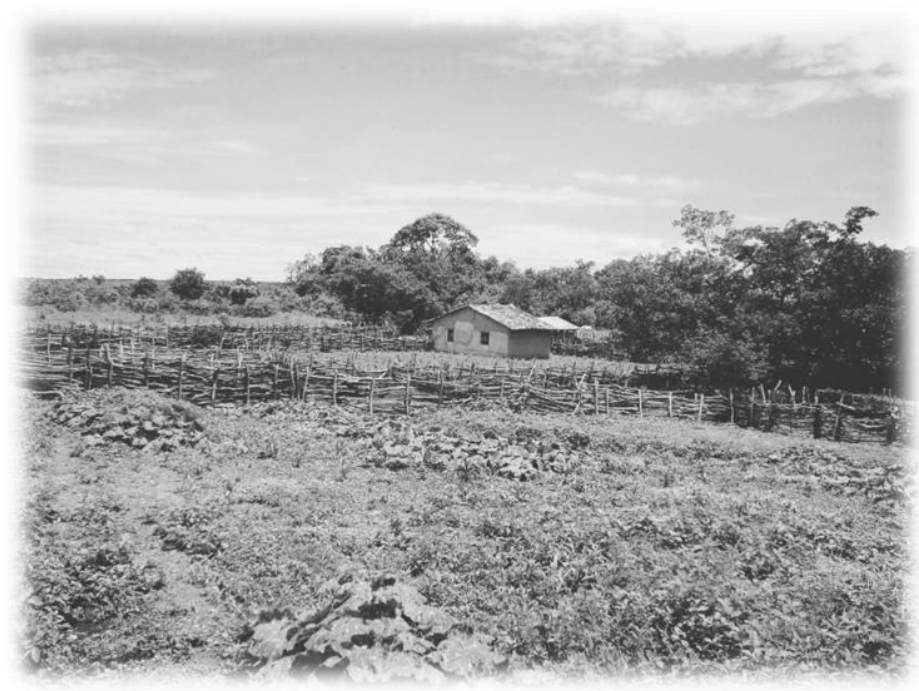

Fonte: Arquivo pessoal (LIMA, 2011)

O mormaço da chuva era sinal de alegria

Vinha o preparo para o plantio

O cuidado com a terra

E a esperança de colheita

E o melhor fruto era sempre você

Sua alegria, pela espera dos frutos da roça.

O melhor fruto do seu plantio é o que me ensinou

Ensinou-me a ser gente

Gente que quer apenas ser um pouco de você

E carregá-lo comigo

Eternamente

Nas entranhas de minh'alma.

Hoje, ao primeiro sinal de chuva

Lembro-me de você

$\mathrm{O}$ inverno me leva pra perto de ti

De teus incansáveis sonhos de lavrador

Que lavrava a terra por amor.

Sinto cheiro da chuva

Sinto cheiro da terra

Sinto falta de você.

(06/12/2017, Teresina (PI), uma noite de insônia) 